\title{
The Factors Influencing Re-Entry Into Entrepreneurship After Failure
}

\author{
María José Ibáñez \\ Universidad del Desarrollo
}

This research aims to estimate the influence of age, entrepreneur household provider status, public financial support, and close business for bankruptcy, on the willingness of the entrepreneur to restart after business failure. The sample include 274 Chilean entrepreneurs who failed in their last entrepreneurial activity and who declare their intention to start again or not. The results suggests that the age and bankruptcy have significant influence, both negative, on the probability of restart-up. This research contributes to identifies the variables that influence the likelihood that an entrepreneur will restart a business after failure. In this vein, the findings may have practical implications on public policy to stimulate the resilience and develop a favorable entrepreneurial ecosystem for serial entrepreneurs.

Keywords: serial entrepreneurship, business failure, reentry, entrepreneurship ecosystem

\section{INTRODUCTION}

It has been widely argued in the literature that entrepreneurial activity is positively related to the economic development of countries and their economic growth (Acs, Estrin, Mickiewicz, \& Szerb, 2018; Kasseeah, 2016; Peprah \& Adekoya, 2020). This highlights the importance of the study of entrepreneurial activity in all its dimensions as a multidisciplinary field of research (Bruyat \& Julien, 2001; Chandra, 2018; Jones, Coviello, \& Tang, 2011; López-Fernández, Serrano-Bedia, \& Pérez-Pérez, 2016). Some of the most researched aspects in entrepreneurship include the study of entrepreneurial intention, entrepreneurial characteristics, and startup failure (Kot, Meyer, \& Broniszewska, 2016; Lecuna, Cohen, \& Chavez, 2017; Zhao, Seibert, \& Hills, 2005; Karimi et al., 2017; Artinger \& Powell, 2016; Khelil, 2016). An emerging area in this discipline concerns what happens to entrepreneurs after business failure and the decision to start a new venture after failing (Corner, Singh, \& Pavlovich, 2017; Lafontaine \& Shaw, 2016). These entrepreneurship aspects open up new opportunities to expand this research field.

Certain entrepreneurs have been identified as negatively affected after entrepreneurial failure in social, psychological, and financial terms (Shepherd, Wiklund, \& Haynie, 2009; Simmons, Wiklund, \& Levie, 2014; Byrne \& Shepherd, 2015). However, there is limited evidence regarding why entrepreneurs might intend to become entrepreneurs after failing (Lafontaine and Shaw, 2016). In this vein, this research aims to identify some factors that may affect the intention of entrepreneurs to start a new business after failing in their previous entrepreneurial activity.

This study implements a probit model to estimate the influence of age, entrepreneur household provider status, public financial support, and close business for bankruptcy, on the willingness of the entrepreneur to restart after business failure. The sample include 274 Chilean entrepreneurs who failed in their last entrepreneurial activity and who declare their intention to start again or not. The results suggests that age 
and bankruptcy have significant influence, both negative, on the probability of restart-up. This research contributes to identifies the variables that influence the likelihood that an entrepreneur will restart a business after failure and the direction of these relations. In this vein, the findings may have practical implications on public policy to stimulate the resilience and develop a favorable entrepreneurial ecosystem for serial entrepreneurs.

This article is organized as follows. Section two presents the literature review and hypotheses development. Section three, shows the research methodological design. The results are presented in section four. In section five, the results are discussed. Finally, limitations and implications are presented in section five.

\section{THEORETICAL BACKGROUND}

Entrepreneurial intent, the characteristics of entrepreneurs and the entrepreneurial ecosystem, and startup failure have overwhelmed the literature in the area of entrepreneurship, leading it to become one of the most popular fields of research in recent times (Karimi et al., 2016; Zhao et al., 2005; Chandra, 2018; Meyer et al., 2014; Shane, 2012; Karimi et al., 2017; Kot et al., 2016; Lecuna et al., 2017; Spigel, 2017; Artinger and Powell, 2016; Khelil, 2016). The positive approach regarding entrepreneurship as an enabler of economic development and growth has led many countries with emerging economies to deploy resources of all kinds to strengthen ecosystems for entrepreneurship and stimulate entrepreneurial activity (Simmons, Wiklund, Levie, Bradley, \& Sunny, 2019; Spigel, 2017; Acs et al., 2018; Kasseeah, 2016; Peprah and Adekoya, n. d.).

The discourse of entrepreneurial activity success has been complemented by the study of business failure of emerging entrepreneurships, leading to interesting conclusions regarding the success and failure determinants of start-ups (Chatterjee and Das, 2016; Dimov and De Clercq, 2006; Pardo and Alfonso, 2017; Song, Podoynitsyna, Van Der Bij, and Halman, 2008). However, the question of what happens to entrepreneurs after business failure still remains. In this regard, valuable contributions have been made regarding the negative psychological, social, and financial consequences of failure for entrepreneurs and their ability to recover from the adverse aspects of failing (Hayward, Forster, Sarasvathy, \& Fredrickson, 2010; Korber \& McNaughton, 2018; Simmons, Carr, Hsu, \& Shu, 2016; Byrne \& Shepherd, 2015; Shepherd \& Cardon, 2009; Simmons et al., 2014). This is the context of the study regarding serial entrepreneurs (Baù, Sieger, Eddleston, \& Chirico, 2017).

Although the field of entrepreneurship has been widely explored in recent years, there is still no unified definition of entrepreneurship or entrepreneur (Bridge, 2017). According to the Global Entrepreneurship Monitor (GEM), entrepreneurship is "any attempt to create a new commercial enterprise or expand an existing enterprise by an individual, a team of individuals, or an established business" (Zacharakis, Bygrave, and Shepherd, 2000). This definition is in line within the importance that the literature attributes to the study of entrepreneurial intention, however, the investigation of entrepreneurial intention depends on the context and the perspective adopted by the researcher (Schlaegel and Koenig, 2014). Therefore, this line of research has taken different paths, with different theoretical and methodological approaches, and in some cases opposing conclusions (Liñán and Fayolle, 2015; Mård, 2020; Shinnar, Giacomin and Janssen, 2012). Studies regarding the decision to establish a business cover demographic, economic and perception variables (attention to opportunities, fear of failure and confidence in one's own abilities) (Arenius and Minniti, 2005). However, the findings are restricted to emerging entrepreneurs, as information about failed entrepreneurs is difficult for researchers to obtain.

Research on entrepreneurship dominantly focuses on success, however, it is common for businesses to fail (Shepherd, Patzelt, \& Wolfe, 2011; Singh, Corner, \& Pavlovich, 2007). In Chile, about 7\% of businesses fail in their initial stage; at the overall national level, 3,593 businesses with terminated bankruptcies were registered in 2016 (SIR, 2016; Guerrero and Serey, 2018). Business failure is part of entrepreneurial dynamics and depends on multiple factors (Alaka et al., 2016). In the same way that the determinants of entrepreneurial success are studied, the determinants of business failure have been studied in the entrepreneurship area, for example, insufficient income for survival, financing problems, problems 
with the execution of the strategic plan, economic or political crises, and lack of indicators or monitoring (Chatterjee and Das, 2016; Pardo and Alfonso, 2017). There is a positive association between entrepreneurial failure and the development and evolution of entrepreneurial ecosystems: entrepreneurs who have experienced failure may be of particular value in driving the evolution of entrepreneurial ecosystems (Simmons et al., 2019).

The nature of entrepreneurial experience can determine how entrepreneurs adapt and influence whether an entrepreneur will start a new business after failing (Ucbasaran, Westhead, Wright, \& Flores, 2010). This positive view, from a systemic point of view, finds its counterpart in the negative consequences that business failure has for some entrepreneurs at the individual level (Jenkins, Wiklund and Brundin, 2014; Shepherd et al., 2011). Not all entrepreneurs who have failed are able to overcome failure and move on with their lives normally (Corner et al., 2017). Studies argue that entrepreneurs who fail experience a variety of negative emotions, such as frustration, distress, disappointment, worry, and embarrassment, among others (Shepherd et al., 2011; 2009). Thus, it is particularly striking that certain people overcome these negative emotions and return to try to establish a business despite failure (Corner et al., 2017). This ability to recover, also called resilience, is generally attributed to some entrepreneurs' overconfidence and attitudes toward failure (Hayward et al., 2010; Korber and McNaughton, 2018). The cognitive skills that distinguish these entrepreneurs to process their business outputs also play an important role in their intentions to engage in serial entrepreneurship (Simmons et al., 2016).

Entrepreneurs who repeatedly start businesses, also called serial entrepreneurs, are more common than people think. A study conducted in Texas revealed that, by 2011, 25.6\% of the state's businesses were operated by serial entrepreneurs (Lafontaine and Shaw, 2016). Another study conducted in Europe states that by 2010 , between 18 and $30 \%$ of entrepreneurs were serial entrepreneurs (Plehn-Dujowich, 2010). What makes failed entrepreneurs try again is an interesting and important research question that has not received significant attention in the literature (Baù et al., 2017). There is evidence that a process of experience accumulation and learning occurs each time the entrepreneur fails and tries again (Guerrero and Peña-Legazkue, 2019; Hsu, Shinnar, Powell, and Coffey, 2017). It has even been found that serial entrepreneurial businesses can be more successful than nascent entrepreneurs and it has been argued that giving space and opportunity for failed entrepreneurs to re-emerge would enhance entrepreneurial activities and improve economic development in countries with emerging economies (Shaw and Sørensen, 2019; Amankwah-Amoah, 2018).

\section{HYPOTHESIS DEVELOPMENT}

From the perspective of the emerging entrepreneur, there is a link between certain demographic and economic variables and the decision to start a business (Arenius and Minniti, 2005). In the case of serial entrepreneurs, diverse relationships have been described between the age, gender, and career path of the failed entrepreneur and his or her decision to try again (Baù et al., 2017; Simmons et al., 2019). For example, younger people are more likely to start a new business than older people, in terms of emerging entrepreneurship (Levesque and Minniti, 2006). Hypothesis 1 tests whether the age affects the probability that the failed entrepreneur return to entrepreneurship.

\section{H1: The older the age of the failed entrepreneur, the lower the probability of starting a business again.}

One dimension that has not been explored is the family context of the serial entrepreneur and how the family's role as provider may influence the decision to restart a business after it has failed. It has been found that there is a positive relationship between family recognition and support towards the entrepreneur and their decision to initiate entrepreneurship (Rambe, 2019). However, for the entrepreneur who plays the role of provider in the family, it may be difficult to move the necessary financial resources to face the losses of the failed business and also to invest in a new business, due to the economic dependence of other family members. In this vein the following hypothesis is proposed. 


\section{H2: Failed entrepreneurs who are household providers are less likely to start a business again.}

Serial entrepreneurs whose previous business failed are likely to assign blame to the external environment (Eggers and Song, 2015). Institutional and regulatory determinants influence entrepreneurial intention, and tend to be different at regional levels, as well as cultural perceptions of entrepreneurial failure (Morales-Alonso, Pablo-Lerchundi and Núñez-Del-Río, 2016; Cardon, Stevens and Potter, 2011). A strong public policies of financial support have a positive influence on nascent entrepreneurial activity, and whether this is also true for the intention to start up again is to be tested.

H3: High levels of public investment in new business development increase the likelihood that failed entrepreneurs will be willing to create a new business.

The reasons for abandoning an entrepreneurship can be varied: retirement, bankruptcy, legal conflicts, health problems, planned closure or preference for a paid work, among others. All these cases are considered business failures, since the company does not remain in business over time (Plehn-Dujowich, 2010). The case of mergers, acquisitions and turnarounds is different, as these circumstances are not considered business failures (INE, 2020). Bankruptcy is the most traumatic reason for leaving the company (SIR, 2016). In the case of small businesses, bankruptcy problems are particularly difficult, since there is no business worth saving and no assets to fight over, so it is the entrepreneur's situation that is of real concern (Baird and Morrison, 2005). Because of the negative psychological, social, and financial consequences of bankruptcy for entrepreneurs, failed entrepreneurs are less likely to try again (Byrne and Shepherd, 2015; Shepherd and Cardon, 2009; Simmons et al., 2014).

H4: Business closure due to bankruptcy reduces the likelihood that the failed entrepreneur will be willing to start a new business.

\section{METHODOLOGY}

This study uses data from the 6th Microentrepreneurship Survey (EME6 - Spanish acronym for Sexta Encuesta de Microemprendimiento), published in 2020 (INE, 2020). The sample includes 274 failed Chilean entrepreneurs, i.e., entrepreneurs whose businesses ceased to operate in 2018 . They are considered failed entrepreneurs since the reasons for the collapse of their companies are not related to a merger, acquisition or other collaborative venture. The sample entrepreneurs were separated by geographic zones in order to incorporate the measures of public investment in financial support for entrepreneurship in each of the 15 regions of Chile for which data are available. The data are first analyzed at a descriptive level, and then a probit model is used to estimate the probability of choosing to start a business again after business failure (Train, 2009). Using the Wald exogeneity test, it was determined that there are no endogeneity problems in the proposed model and, therefore, the use of instrumental variables is not required (Stock and Watson, 2012).

The dependent variable is the failed entrepreneur's intention to start a new company, this variable take value one if the entrepreneur is willing to restart a business and zero otherwise. Four independent variables are specified: age, provider, bankruptcy, and public financial support. The age of failed entrepreneur is code in five categories. The provider variable represents the role of main financial support of the entrepreneur's family, takes value one if the entrepreneur is the main household provider and zero otherwise. As a proxy for public financial support, the number of entrepreneurship projects approved for public financing through instruments of the Development Corporation (Corfo) was used, constructed at the regional level and weighted by the number of inhabitants in each of the regions. The bankruptcy variable is measured by the answer to sentence 'the company's closure was due to the fact that the business did not produce sufficient income', takes value one if the response is yes and zero if the response is no.

Five additional control variables are used: gender, regional unemployment rate, educational level, whether the reason for closing the business was that the entrepreneur got a paid work, and infrastructure 
for entrepreneurship, measured by the number of offices of the Technological Cooperation Service (Sercotec) weighted by the number of inhabitants in each of the regions. The conceptual definitions and coding/operationalization of the variables are described in Appendix 1 and Appendix 2.

Entrepreneurs who are willing to restart a business after failing represent about $70 \%$ of the sample. Most failed entrepreneurs are between 45 years old and 64 years old, and about $45 \%$ of failed entrepreneurs have only completed high school. In addition, $32 \%$ of failed entrepreneurs report bankruptcy as a reason for failure. The public financial support provided by Corfo is below $1 \%$ regional coverage. Most of the entrepreneurs who intend to start up again are located in the central zone of the country, which includes regions V, VI, VII and VIII and the Metropolitan Region. Coincidentally, the largest number of Sercotec offices are located in the central zone, where almost $57 \%$ of the total national coverage is located. Of the total number of projects supported by Corfo, $66 \%$ of these projects are located in the central zone and almost $40 \%$ only in the Metropolitan Region.

\section{RESULTS}

Table 1 reports the results of the probit analysis and the marginal effects and the level of correct classification of the model.

TABLE 1

PROBIT MODEL RESULTS

\begin{tabular}{lllll}
\hline Variable & Coef. & S.d. & dx / dx & S.d. \\
\hline Age & $-0.148^{* *}$ & 0.070 & $-0.050^{* *}$ & 0.024 \\
Provider $\sim$ & -0.041 & 0.190 & -0.014 & 0.065 \\
Coverage financial support & 723.0 & 7281.1 & 246.6 & 2483.8 \\
Technical support coverage & $-90255.8^{* *}$ & 44326.9 & $-30787.7^{* *}$ & 15101 \\
Bankruptcy $~$ & $-0.561^{* *}$ & 0.229 & $-0.199^{* *}$ & 0.083 \\
Job opportunity $\sim$ & $-0.648^{* * *}$ & 0.225 & $-0.225^{* * *}$ & 0.078 \\
Gender $\sim$ & 0.241 & 0.185 & 0.084 & 0.065 \\
Unemployment & $-0.129^{*}$ & 0.075 & $-0.044^{*}$ & 0.026 \\
Educational level & -0.079 & 0.084 & -0.027 & 0.029 \\
Constant & $2.812^{* * *}$ & 0.741 & & \\
Pseudo R-Square & 0.069 & & & \\
Correct classification & $70.07 \%$ & & & \\
Observations & 274 & & & \\
\hline Nos: S.d. Stalis & . & & & \\
\hline
\end{tabular}

Notes: S.d. $=$ Standard Deviation. $* / * * / * * *$ significance level at $0.10 / 0.05 / 0.01 .(\sim)$ dy/dx is marginal effects for discrete changes in the binary variable from 0 to 1 .

The relationship between the age of the failed entrepreneur and his or her intention to re-start is negative and significant. Specifically, the increase of age in one category leads a decrease of probability to restart a business in $0.05 \%$ (S.d. $=0.02 ; \rho<0.05$ ), therefore, hypothesis 1 is support. It is found that there is a negative relationship between being a family provider and the probability of starting a new business after failure. However, this relationship is not significant, therefore, hypothesis 2 is reject. Regarding hypothesis 3 , the public financial support for entrepreneurship do not have significant influence on the probability of starting a new business after having failed; therefore, this hypothesis is rejected.

The influence of business closure because the business did not generate enough revenue is negative and significant, i.e., those failed entrepreneurs who have experienced bankruptcy will be less likely to undertake again relative to entrepreneurs who have closed their businesses for other causes. Specifically, the entrepreneurs who experience the bankruptcy have a $19.9 \%($ S.d. $=0.08 ; \rho<0.05)$ less probability to restart a business. Therefore, hypothesis 4 is support. 


\section{DISCUSSION AND CONCLUSIONS}

This research aims to determine the factors that influence the willingness to restart after business failure, specifically age, entrepreneur household provider status, the bankruptcy as the reason to close the business, and public financial support. A probit model is conducted to test the proposed hypotheses, using a sample of 274 failed entrepreneurs from Chile. The findings suggest that the age and bankruptcy have a significant influence, both negative, in the willingness to restart a business after failure.

Entrepreneurship intention refers mainly to first-time entrepreneurs, but could also apply to serial entrepreneurs who have not experienced business failures (Karimi et al., 2017). In turn, the intention to start entrepreneurship after an entrepreneurial failure covers different dimensions, and the intention to restart-up may be influence by factors differs to entrepreneurial intention drivers (Tipu, 2020). Therefore, there may be less coincidence between the intention to start entrepreneurship again after failure and the number of emerging first-time entrepreneurships. This study detected a high level of intention to start a new entrepreneurship among the entrepreneurs in the sample, as almost $70 \%$ of them were willing to start a new business after having failed in their previous one.

Baù et al. (2017) argue that age has a nonlinear relationship with the probability of re-entering entrepreneurship, under a career development approach. This argument is interesting in the case where entrepreneurs have career expectations. However, not all entrepreneurs have the education levels required for career development and, in some cases, the stages in career development are not related to age, but rather to access to opportunities. In this study, age has a negative and significant influence on the probability of re-entry into entrepreneurship, in line with Levesque and Minniti (2006). On the other hand, the results showed that only $28 \%$ of failed entrepreneurs had experienced bankruptcy, and this reason for failure had a negative and significant influence on the likelihood of re-starting a business after failure. This supports the findings of Corner et al. (2017) regarding it not being a common pattern for people to overcome these negative experiences and detracts from the positive influence of learning accumulation on entrepreneurial failure (Hsu et al., 2017). The negative relationship between the reasons for business failure and the intention to create a new business may indicate that there is indeed a correction regarding the perception of risk and a modification of the entrepreneur's behavior after business failure, which had already been raised in terms of the distinction between entrepreneurial intention and intention to re-start a business (Overall, 2016).

It has been argued how entrepreneurs who have experienced failure may have particular value in driving the evolution of entrepreneurial ecosystems (Simmons et al., 2019). This study explored the influence of government support through financing for entrepreneurship on the likelihood of entrepreneurs to start a business again after failure. The findings suggest that the coverage of financial support to entrepreneurs does not have a significant influence on the probability of re-starting entrepreneurship. This result may be explained because most of the financing and support instruments for entrepreneurship are aimed at emerging entrepreneurs, therefore, the benefits of these hedges for the serial entrepreneur may be minimal (Corfo, 2020b). In addition, many financial institutions have strict lending requirements that include the evaluation of the entrepreneur's previous business experience, then the ecosystem for serial entrepreneurship is not sufficiently developed at the moment, at least in terms of financing instruments to restart-up (Spigel, 2017). This reaffirms the importance of the entrepreneur's level of wealth that allows $\mathrm{him} /$ her to be a serial entrepreneur, since in the face of the difficulty of obtaining external financial support, he/she will have to face the loss of the previous business and the investment in the new one through alternative sources or own resources (Vereshchagina and Hopenhayn, 2009).

\section{LIMITATIONS AND IMPLICATIONS}

This research contributes to identify the factors that influence the willingness to undertake after business failure, and the directions of these relations. A limitation to the study of re-entry into entrepreneurship after business failure lies in the limited information on failed entrepreneurs. For the most part, these entrepreneurs disappear from observations in entrepreneurship surveys, which, in general, are 
not longitudinal. For this type of study, it is important to distinguish between necessity and opportunity entrepreneurs, since there is a strong substitution between paid work opportunities and the intention to start a business after business failure. We could be dealing with pass-through entrepreneurships, i.e., companies that are created to earn income while waiting to enter the formal labor market as an employee.

This research uses data from Chile, the country with the highest rate of early-stage entrepreneurial activity (TEA) in the world, according to the Global Entrepreneurship Monitor (GEM) (Bosma et al., 2020). Therefore, there could be significant differences in the conclusions of a similar study in other countries of the world with lower rates of entrepreneurial activity. In order to better understand the role of failed entrepreneurs in the entrepreneurial ecosystem, it is necessary to have better variables related to the structural, regulatory and institutional aspects that characterize these entrepreneurial ecosystems. However, it is difficult to conceptualize these variables and, in this sense, it would be interesting to combine qualitative and quantitative methods for a more in-depth approach to the problem.

The results may suggest that there is no integrated dimension to the entrepreneurial ecosystem that includes serial entrepreneurs. In this vein, it is important to design public policies and promotion instruments especially aimed at entrepreneurs who have failed and are willing to try again. Thus, the debate can flow in three directions: the first related to the development of instruments aimed at avoiding business failure or reducing losses through a planned business closure, such as, for example, support programs for low-growth or poorly performing entrepreneurships; a second directive could be to include the restart entrepreneurship in the portfolio of projects eligible for public financing through Corfo or government guarantee aimed at private bank loans. Finally, to implement a communication strategy that promotes resilience as a desirable characteristic in entrepreneurs, softening the idealist discourse about entrepreneurial activity success. For the time being, bankruptcy regulations in Chile have been adapted to facilitate the closure of failed businesses and mitigate the losses of their owners (SIR, 2016). However, it is necessary to consider not only the negative financial consequences of a failed entrepreneurship, but also the psychological and social costs that affect the failed entrepreneur.

\section{ACKNOWLEDGEMENTS}

The author thanks Multidisciplinary Business Review Editor-in-Chief José Rojas-Méndez and the Ethics Committee. The author acknowledge the financial support during her PhD studies from the Facultad de Economía y Negocios at the Universidad del Desarrollo in Chile.

This article has been published in its Spanish version in the journal Multidiscplinary Business Review. (Original reference: Ibáñez Caamaño, M. J. (2020). Reingreso al emprendimiento después del fracaso: Factores que influyen sobre los emprendedores seriales y de segunda oportunidad. Multidisciplinary Business Review, 13(1), 31-42.) This translation has been authorized and recognizes the copyrights of Multidisciplinary Business Review.

Translated \& edited by American Publishing Services (https://americanpublishingservices.com/).

\section{REFERENCES}

Acs, Z.J., Estrin, S., Mickiewicz, T., \& Szerb, L. (2018). Entrepreneurship, institutional economics, and economic growth: An ecosystem perspective. Small Business Economics, 51(2), 501-514.

Alaka, H.A., Oyedele, L.O., Owolabi, H.A., Ajayi, S.O., Bilal, M., \& Akinade, O.O. (2016). Methodological approach of construction business failure prediction studies: A review. Construction Management and Economics, 34(11), 808-842.

Amankwah-Amoah, J. (2018). Revitalising serial entrepreneurship in Sub-Saharan Africa: Insights from a newly emerging economy. Technology Analysis \& Strategic Management, 30(5), 499-511.

Arenius, P., \& Minniti, M. (2005). Perceptual variables and nascent entrepreneurship. Small Business Economics, 24(3), 233-247.

Artinger, S., \& Powell, T.C. (2016). Entrepreneurial failure: Statistical and psychological explanations. Strategic Management Journal, 37(6), 1047-1064. 
åShinnar, R.S., Giacomin, O., \& Janssen, F. (2012). Entrepreneurial perceptions and intentions: The role of gender and culture. Entrepreneurship Theory and Practice, 36(3), 465-493.

Audretsch, D.B., Carree, M.A., Thurik, R., \& Van Stel, A.J. (2005). Does self-employment reduce unemployment? Journal of Business Venturing, 23(6), 673-686.

Baird, D.G., \& Morrison, E.R. (2005). Serial entrepreneurs and small business bankruptcies. Columbia Law Review, 105, 2310-2368.

Baù, M., Sieger, P., Eddleston, K.A., \& Chirico, F. (2017). Fail but try again? The effects of age, gender, and multiple-owner experience on failed entrepreneurs' reentry. Entrepreneurship Theory and Practice, 41(6), 909-941.

Bosma, N., Hill, S., Ionescu-Somers, A., Kelley, D., Levie, J., \& Tarnawa, A. (2020). GEM 2019/2020 Global Report. Gem Mundial 2019/2020. Retrieved from https://www.gemconsortium.org/file/open?fileId=50443

Bridge, S. (2017). Does 'entrepreneurship' exist? Small Enterprise Research, 24(2), 206-213.

Bruyat, C., \& Julien, P-A. (2001). Defining the field of research in entrepreneurship. Journal of Business Venturing, 16(2), 165-180.

Byrne, O., \& Shepherd, D.A. (2015). Different strokes for different folks: Entrepreneurial narratives of emotion, cognition, and making sense of business failure. Entrepreneurship Theory and Practice, 39(2), 375-405.

Cardon, M.S., Stevens, C.E., \& Potter, D.R. (2011). Misfortunes or mistakes?: Cultural sensemaking of entrepreneurial failure. Journal of Business Venturing, 26(1), 79-92.

Chandra, A., \& Medrano-Silva, M.A. (2012). Business incubation in Chile: Development, financing and financial services. Journal of Technology Management \& Innovation, 7(2), 1-13.

Chandra, Y. (2018). Mapping the evolution of entrepreneurship as a field of research (1990-2013): A scientometric analysis. PloS One, 13(1).

Chatterjee, N., \& Das, N. (2016). A study on the impact of key entrepreneurial skills on business success of Indian micro-entrepreneurs: A case of Jharkhand region. Global Business Review, 17(1), 226237.

Corfo. (2020a). Página principal. Retrieved from https://www.corfo.cl/sites/cpp/home

Corfo. (2020b). Programas y convocatorias. Retrieved from https://www.corfo.cl/sites/cpp/programas-yconvocatorias

Corner, P.D., Singh, S., \& Pavlovich, K. (2017). Entrepreneurial resilience and venture failure. International Small Business Journal, 35(6), 687-708.

Dimov, D., \& De Clercq, D. (2006). Venture capital investment strategy and portfolio failure rate: A longitudinal study. Entrepreneurship Theory and Practice, 30(2), 207-223.

Eggers, J.P., \& Song, L. (2015). Dealing with failure: Serial entrepreneurs and the costs of changing industries between ventures. Academy of Management Journal, 58(6), 1785-1803.

Guerrero, M., \& Peña-Legazkue, I. (2019). Renascence after post-mortem: The choice of accelerated repeat entrepreneurship. Small Business Economics, 52(1), 47-65.

Guerrero, M., \& Serey, T. (2018). Reporte Nacional de Chile 2018. Global Entrepreneurship Monitor.

Hayward, M.L.A., Forster, W.R., Sarasvathy, S.D., \& Fredrickson, B.L. (2010). Beyond hubris: How highly confident entrepreneurs rebound to venture again. Journal of Business Venturing, 25(6), 569-578.

Hsu, D.K., Shinnar, R.S., Powell, B.C., \& Coffey, B.S. (2017). Intentions to reenter venture creation: The effect of entrepreneurial experience and organizational climate. International Small Business Journal, 35(8), 928-948.

Ibáñez Caamaño, M.J. (2020). Reingreso al emprendimiento después del fracaso: Factores que influyen sobre los emprendedores seriales y de segunda oportunidad. Multidisciplinary Business Review, 13(1), 31-42. https://doi.org/10.35692/07183992.13.1.4

INE. (2020). Sexta Encuesta de Microemprendimiento. Miisterio de Economía, Chile. Retrieved from https://www.economia.gob.cl/2020/03/11/sexta-encuesta-de-microemprendimiento-eme6.htm

134 Journal of Applied Business and Economics Vol. 23(7) 2021 
Jenkins, A.S., Wiklund, J., \& Brundin, E. (2014). Individual responses to firm failure: Appraisals, grief, and the influence of prior failure experience. Journal of Business Venturing, 29(1), 17-33.

Jones, M.V., Coviello, N., \& Tang, Y.K. (2011). International entrepreneurship research (1989-2009): A domain ontology and thematic analysis. Journal of Business Venturing, 26(6), 632-659.

Karimi, S., Biemans, H.J.A., Lans, T., Chizari, M., \& Mulder, M. (2016). The impact of entrepreneurship education: A study of Iranian students' entrepreneurial intentions and opportunity identification. Journal of Small Business Management, 54(1), 187-209.

Karimi, S., Biemans, H.J.A., Naderi Mahdei, K., Lans, T., Chizari, M., \& Mulder, M. (2017). Testing the relationship between personality characteristics, contextual factors and entrepreneurial intentions in a developing country. International Journal of Psychology, 52(3), 227-240.

Kasseeah, H. (2016). Investigating the impact of entrepreneurship on economic development: A regional analysis. Journal of Small Business and Enterprise Development, 23(3), 896-916.

Khelil, N. (2016). The many faces of entrepreneurial failure: Insights from an empirical taxonomy. Journal of Business Venturing, 31(1), 72-94.

Korber, S., \& McNaughton, R.B. (2018). Resilience and entrepreneurship: A systematic literature review. International Journal of Entrepreneurial Behavior \& Research, 24(7), 1129-1154.

Kot, S., Meyer, N., \& Broniszewska, A. (2016). A cross-country comparison of the characteristics of Polish and South African woman entrepreneurs. Economics and Sociology, 9(4), 207-221.

Lafontaine, F., \& Shaw, K. (2016). Serial entrepreneurship: Learning by doing? Journal of Labor Economics, 34(S2), S217-S254.

Lecuna, A., Cohen, B., \& Chavez, R. (2017). Characteristics of high-growth entrepreneurs in Latin America. International Entrepreneurship and Management Journal, 13(1), 141-159.

Levesque, M., \& Minniti, M. (2006). The effect of aging on entrepreneurial behavior. Journal of Business Venturing, 21(2), 177-194.

Liñán, F., \& Fayolle, A. (2015). A systematic literature review on entrepreneurial intentions: Citation, thematic analyses, and research agenda. International Entrepreneurship and Management Journal, 11(4), 907-933.

López-Fernández, M.C., Serrano-Bedia, A.M., \& Pérez-Pérez, M. (2016). Entrepreneurship and family firm research: A bibliometric analysis of an emerging field. Journal of Small Business Management, 54(2), 622-639.

Mård, M. (2020). Book review: A research agenda for entrepreneurial cognition and intention. Londres: SAGE Publications.

Meyer, M., Libaers, D., Thijs, B., Grant, K., Glänzel, W., \& Debackere, K. (2014). Origin and emergence of entrepreneurship as a research field. Scientometrics, 98(1), 473-485.

Morales-Alonso, G., Pablo-Lerchundi, I., \& Núñez-Del-Río, M-C. (2016). Intención emprendedora de los estudiantes de ingeniería e influencia de factores contextuales. Revista de Psicología Social, $31(1), 75-108$.

Morgan, J., \& Sisak, D. (2016). Aspiring to succeed: A model of entrepreneurship and fear of failure. Journal of Business Venturing, 31(1), 1-21.

Overall, J. (2016). The dark side of entrepreneurship: A conceptual framework of cognitive biases, neutralization, and risky entrepreneurial behaviour. Academy of Entrepreneurship Journal, 22(2), $1-12$.

Pardo, C., \& Alfonso, W. (2017). Applying "attribution theory" to determine the factors that lead to the failure of entrepreneurial ventures in Colombia. Journal of Small Business and Enterprise Development, 24(3), 562-584.

Păunescu, C., Popescu, M.C., \& Duennweber, M. (2018). Factors determining desirability of entrepreneurship in Romania. Sustainability, 10(11), 3893, 1-22.

Peprah, A.A., \& Adekoya, A.F. (2020). Entrepreneurship and economic growth in developing countries: Evidence from Africa. Business Strategy and Development. doi: 10.1002/bsd2.104

Plehn-Dujowich, J. (2010). A theory of serial entrepreneurship. Small Business Economics, 35(4), $377-$ 398. 
Rambe, P. (2019). The influence of selected personal demographic and institutional variables on venture creation: A case of small technology-oriented ventures in an emerging economy. African Journal of Science, Technology, Innovation and Development, 11(1), 13-28.

Schlaegel, C., \& Koenig, M. (2014). Determinants of entrepreneurial intent: A meta-analytic test and integration of competing models. Entrepreneurship Theory and Practice, 38(2), 291-332.

Sercotec. (2020). Página principal. Retrieved from https://www.sercotec.cl/

Shane, S. (2012). Delivering on the promise of entrepreneurship as a field of research. Academy of Management Review, 37(1), 10-20.

Shaw, K., \& Sørensen, A. (2019). The productivity advantage of serial entrepreneurs. ILR Review, 72(5), $1225-1261$.

Shepherd, D.A., \& Cardon, M.S. (2009). Negative emotional reactions to project failure and the selfcompassion to learn from the experience. Journal of Management Studies, 46(6), 923-949.

Shepherd, D.A., Patzelt, H., \& Wolfe, M. (2011). Moving forward from project failure: Negative emotions, affective commitment, and learning from the experience. Academy of Management Journal, 54(6), 1229-1259.

Shepherd, D.A., Wiklund, J., \& Haynie, J.M. (2009). Moving forward: Balancing the financial and emotional costs of business failure. Journal of Business Venturing, 24(2), 134-148.

Simmons, S.A., Carr, J.C., Hsu, D.K., \& Shu, C. (2016). The regulatory fit of serial entrepreneurship intentions. Applied Psychology, 65(3), 605-627.

Simmons, S.A., Wiklund, J., \& Levie, J. (2014). Stigma and business failure: Implications for entrepreneurs' career choices. Small Business Economics, 42(3), 485-505.

Simmons, S.A., Wiklund, J., Levie, J., Bradley, S.W., \& Sunny, S.A. (2019). Gender gaps and reentry into entrepreneurial ecosystems after business failure. Small Business Economics, 53(2), 517531.

Singh, S., Corner, P., \& Pavlovich, K. (2007). Coping with entrepreneurial failure. Journal of Management \& Organization, 13(4), 331-344.

SIR. (2016). Boletín Estadístico de Quiebras. Chile: Superintendencia de Insolvencia y Reemprendimiento.

Song, M., Podoynitsyna, K., Van Der Bij, H., \& Halman, J. I. M. (2008). Success factors in new ventures: A meta-analysis. Journal of Product Innovation Management, 25(1), 7-27.

Spigel, B. (2017). The relational organization of entrepreneurial ecosystems. Entrepreneurship: Theory and Practice, 41(1), 49-72.

Stock, J., \& Watson, M. (2012). Introducción a la econometría ( $3^{\mathrm{a}}$ ed.). Madrid: Pearson Educación.

Tipu, S.A.A. (2020). Entrepreneurial reentry after failure: A review and future research agenda. Journal of Strategy and Management, 13(2), 198-220.

Train, K.E. (2009). Discrete choice methods with simulation (2a ed.). Cambridge University Press.

Ucbasaran, D., Westhead, P., Wright, M., \& Flores, M. (2010). The nature of entrepreneurial experience, business failure and comparative optimism. Journal of Business Venturing, 25(6), 541-555.

Vereshchagina, G., \& Hopenhayn, H. A. (2009). Risk taking by entrepreneurs. American Economic Association, 99(5), 1808-1830.

Zacharakis, A., Bygrave, W.D., \& Shepherd, D.A. (2000). Global entrepreneurship monitor: National entrepreneurship assessment, United States of America: 2000 executive Report. Kauffman Center for Entrepreneurial Leadership at the Ewing Marion Kauffman.

Zhao, H., Seibert, S.E., \& Hills, G.E. (2005). The mediating role of self-efficacy in the development of entrepreneurial intentions. Journal of Applied Psychology, 90(6), 1265. 


\section{APPENDIX 1: DESCRIPTIVE STATISTICS FOR DISCRETE VARIABLES}

\begin{tabular}{|c|c|c|}
\hline Variables & & $\begin{array}{c}\text { Share } \\
\%\end{array}$ \\
\hline Re-start an entrepreneurship & Failed entrepreneur's intention to start a new company. & \\
\hline $0=$ No & & 30.29 \\
\hline $1=$ Yes & & 69.71 \\
\hline Age & Age of failed entrepreneur in stages. & \\
\hline $1=$ Between 15 and 24 years old & & 9.490 \\
\hline $2=$ Between 25 and 34 years old & & 16.42 \\
\hline $3=$ Between 35 and 44 years old & & 15.69 \\
\hline $4=$ Between 45 and 54 years old & & 26.28 \\
\hline $5=$ Between 55 and 64 years old & & 23.72 \\
\hline $6=65$ years old or more & & 8.390 \\
\hline Educational level & Higher educational level achieved by the entrepreneur. & \\
\hline $1=$ No formal education & & 2.190 \\
\hline $2=$ Elementary education & & 27.01 \\
\hline $3=$ High school education & & 44.89 \\
\hline $4=$ Technical higher education & & 9.120 \\
\hline $5=$ University higher education & & 16.06 \\
\hline $6=$ Master's degree & & 0.730 \\
\hline Provider & Role of main financial support of the entrepreneur's family. & \\
\hline $0=$ Not a provider & & 45.62 \\
\hline $1=$ Provider & & 54.38 \\
\hline Bankruptcy & The company's closure because did not produce sufficient income. & \\
\hline $0=\mathrm{No}$ & & 68.25 \\
\hline $1=$ Yes & & 31.75 \\
\hline Job opportunities & The company's closure because the entrepreneur got a paid work. & \\
\hline $0=\mathrm{No}$ & & 59.49 \\
\hline $1=$ Yes & & 40.51 \\
\hline Gender & Gender with which the entrepreneur is identified. & \\
\hline $0=$ Female & & 34.67 \\
\hline $1=$ Male & & 65.33 \\
\hline Observations & & 274 \\
\hline
\end{tabular}

\section{APPENDIX 2: DESCRIPTIVE STATISTICS FOR CONTINUOUS VARIABLES}

\begin{tabular}{llll}
\hline Variables & & Mean & S.d. \\
\hline Financial support & $\begin{array}{l}\text { Number of entrepreneurship projects approved for public } \\
\text { financing weighted by population at regional level. }\end{array}$ & $2.84 \times 10^{-5}$ & $1.42 \times 10^{-5}$ \\
$\begin{array}{l}\text { Technical } \\
\text { support }\end{array}$ & $\begin{array}{l}\text { Number of offices of Sercotec weighted by population at } \\
\text { Unemployment }\end{array}$ & $\begin{array}{l}\text { regional level. } \\
\text { Rate of unemployment at regional level. }\end{array}$ & $6.54 \times 10^{-6}$ \\
\hline
\end{tabular}

